\title{
Pemanfaatan Mikroalga dalam Penurunan Kadar Amonia dengan Variasi Penambahan Effective Microorganism
}

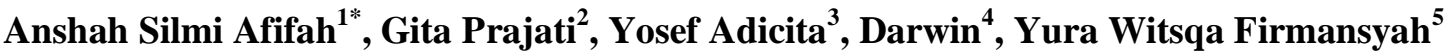 \\ ${ }^{1,2,3,4}$ Prodi Teknik Lingkungan, Fakultas Teknik, Universitas Universal Batam \\ ${ }^{5}$ Prodi Magister Kesehatan Lingkungan, Fakultas Kesehatan Masyarakat, Universitas Diponegoro Semarang \\ *Koresponden email: anshah.silmi@gmail.com
}

Diterima: 5 Januari 2021

Disetujui: 3 Maret 2021

\begin{abstract}
The existence of microalgae in water -provides many benefits especially for biological treatments of wastewater. Microalgae have many species and are chlorophyll microorganisms. Photosynthesis carried out by microalgae requires essential nutrients such as $\mathrm{CO}_{2}$. Carbon dioxide can be obtained by symbiosis from other microorganisms, such as EM4, which can be used to decompose complex organic compounds into simple compounds $\left(\mathrm{CO}_{2}\right)$. The addition of EM4 must be appropriate to make the photosynthesis process in microalgae take place optimally. Therefore, this study aims to determine the optimal dose variation of EM4 in the microalgae in the reactor. With variations in the doses tested were $0 \mathrm{~mL}, 1 \mathrm{~mL}$, and $2 \mathrm{~mL}$. The research was conducted by making artificial wastewater from liquid NPK, diluting it with tap water with a ratio of 1:300. The test was carried out using a batch system, with solar lighting and aeration for 24 hours. The result of the best dose variation is the addition of $1 \mathrm{~mL}$ of EM4. The largest decrease in ammonia levels is obtained which is then compared to the variation of the doses of $0 \mathrm{~mL}$ and $2 \mathrm{~mL}$.
\end{abstract}

Keywords: wastewater, ammonia, microalgae, EM4, NPK

\begin{abstract}
Abstrak
Keberadaan mikroalga di perairan memiliki banyak manfaat, seperti untuk pengolahan biologis air limbah. Mikroalga memiliki banyak spesies serta merupakan mikoorganisme yang berklorofil. Fotosintesis yang dilakukan mikroalga membutuhkan nutrien esensial seperti $\mathrm{CO}_{2}$. Karbon dioksida dapat diperoleh dengan simbiosis dari mikroorganisme lain, seperti EM4 yang bisa dimanfaatkan sebagai pengurai senyawa organik kompleks menjadi senyawa sederhana $\left(\mathrm{CO}_{2}\right)$. Penambahan EM4 harus sesuai, agar proses fotosintesis pada mikroalga dapat berlangsung secara optimal. Oleh karena itu, penelitian ini bertujuan untuk mengetahui variasi dosis optimal EM4 pada mikroalga dalam reaktor. Dengan variasi dosis yang diujikan adalah $0 \mathrm{~mL}, 1 \mathrm{~mL}$, dan $2 \mathrm{~mL}$. Penelitian dilakukan dengan membuat air limbah artifisial dari NPK cair, dilarutkan dengan air kran perbandingan $1: 300$. Pengujian dilakukan dengan sistem batch, dengan perlakuan pencahayaan matahari dan aerasi selama 24 jam. Hasil variasi dosis terbaik adalah dengan ditambahkan EM4 sebesar $1 \mathrm{~mL}$ serta didapatkan penurunan kadar amonia paling besar dibandingkan dengan variasi dosis $0 \mathrm{~mL}$ dan $2 \mathrm{~mL}$.
\end{abstract}

Kata Kunci: air limbah, amonia, mikroalga, EM4, NPK.

\section{Pendahuluan}

Indonesia memiliki keanekaragaman hayati yang besar, salah satunya adalah mikroalga. Keberadaan mikroalga banyak dijumpai di perairan, dan persebarannya merata mulai dari muka perairan hingga ke dasar perairan yakni lapisan sedimen [1]. Mikroalga memiliki banyak kegunaan. Chlorella vulgaris merupakan jenis alga yang memiliki komponen penyusun 54\% total protein, $18,6 \%$ total karbohidrat, 30,5\% total lemak, dan 3,5\% asam nukleat. Mikroalga jenis ini berpotensi untuk menjadi sumber alternatif pengganti bahan bakar saat ini [2]. Kebutuhan energi yang semakin meningkat menyebabkan sumber energi semakin berkurang. Hal ini mendorong pencarian sumber energi terbarukan untuk mengantisipasi kelangkaan tersebut. Salah satu sumber energi baru adalah mikroalga [1]. Chlorella vulgaris mampu memproduksi biodiesel sebesar 72,54\% [3]. Oleh sebab itu pertumbuhan biomassa mikroalga menjadi menarik untuk diteliti.

Mikroalga merupakan organisme eukariotik berukuran 1-10 $\mu \mathrm{m}$ yang memiliki efektifitas mereduksi polutan limbah cair [4]. Chlorella pyrenoidosa merupakan jenis alga hijau yang mampu mereduksi nitrat $60 \%$, ammonia hingga $100 \%$, total nitrogen $75,7-82,5 \%$, fosfat $62,5-87 \%$, dan COD 
27,4 - 38,4\% [5]. Reduksi tersebut disebabkan karena dalam pertumbuhannya, mikroalga membutuhkan nutrien seperti N-amonia, N-nitrat, N-nitrit, fosfat, dan lain-lain [6].

Mikroalga juga merupakan jenis mikroorganisme autotrof, sehingga dalam pertumbuhannya mikroalga membutuhkan cahaya dan $\mathrm{CO}_{2}$ untuk berfotosintesis [7]. Kebutuhan karbondioksida bisa didapatkan dari mikroorganisme lain seperti bakteri. Bakteri mampu mengubah karbohidrat kompleks menjadi $\mathrm{CO}_{2}$ sehingga bisa digunakan oleh mikroalga untuk proses fotosintesis. EM4 mengandung lima jenis bakteri, keberadaannya di limbah cair mampu mendegradasi senyawa organik lebih cepat dibanding hanya menggunakan mikroorganisme alami dalam limbah cair [8]. Penelitian ini bertujuan untuk mengetahui dosis penambahan EM4 yang tepat terhadap pertumbuhan mikroorganisme (mikroalga + EM4) dan mengetahui kemampuan mikroorganisme tersebut dalam menurunkan kadar amonia.

\section{Metode Penelitian}

\section{Waktu dan Tempat Penelitian}

Penelitian ini dilaksanakan di Laboratorium Teknik Lingkungan, Fakultas Teknik, Universitas Universal dari bulan April 2020 sampai dengan bulan September 2020. Metode dilakukan menggunakan sistem batch teraerasi. Selama penelitian volume air limbah yang digunakan tetap.

\section{Alat dan Bahan}

Alat yang digunakan pada penelitian ini adalah reaktor berbahan kaca dengan kapasitas $250 \mathrm{~mL}$, aerator, diffuser, selang penghubung antara aerator dan reaktor, dan valve pengatur debit udara dari aerator. Bahan yang digunakan pada penelitian ini adalah Air PDAM, nutrien (NPK cair), bibit mikroalga, dan EM4.

\section{Prosedur Kerja}

Penelitian dilakukan dengan menyiapkan reaktor yang terbuat dari bahan kaca, dengan kapasitas $250 \mathrm{~mL}$ sebanyak 3 unit. Masing-masing reaktor diisikan dengan air limbah artifisial, yang dibuat dari air kran $150 \mathrm{~mL}$ dan NPK cair 0,5 mL. NPK cair yang ditambahkan merupakan NPK cair yang banyak terdapat di pasaran. Kandungan dari NPK tersebut yaitu senyawa-senyawa organik dan unsur-unsur makro seperti nitrogen, senyawa $\mathrm{P}_{2} \mathrm{O}_{5}$, dan senyawa $\mathrm{K}_{2} \mathrm{O}$. Senyawa-senyawa organik dan unsur-unsur makro tersebut dibutuhkan untuk proses fotosintesis [9] mikroalga. Masing-masing reaktor dikondisikan dengan variasi yang berbeda-beda yaitu :

- Variasi 1 (V1) reaktor dikondisikan dengan menambahkan mikroalga $50 \mathrm{~mL}$ dan EM4 $0 \mathrm{~mL}$.

- Variasi 2 (V2) reaktor dikondisikan dengan menambahkan mikroalga $49 \mathrm{~mL}$ dan EM4 $1 \mathrm{~mL}$.

- Variasi 3 (V3) reaktor dikondisikan dengan menambahkan mikroalga 48 mL dan EM4 2 mL.

Masing-masing reaktor diberikan aerasi selama 24 jam dan dikontakkan dengan cahaya matahari. Cahaya matahari dibutuhkan sebagai sumber energi untuk proses fotosintesis mikroalga [6].

\section{Hasil dan Pembahasan}

Pengamatan pada setiap variasi perlakuan dilakukan dengan mengambil sampel pada masingmasing variabel. Pengambilan sampel dilakukan dengan mengambil $10 \mathrm{ml}$ sampel untuk kemudian diuji nilai kekeruhan dan nilai amonia. berdasarkan penelitian yang dilakukan oleh [10], dijelaskan bahwa nilai kekeruhan dalam perairan biasanya digunakan sebagai indikator untuk menunjukkan tingginya bahan organik dan mikroorganisme perairan. Dalam penelitian digunakan sistem batch, dimana tidak terdapat penambahan air limbah selama penelitian berlangsung. Air limbah dimaksud merupakan air limbah artifisial yang dibuat dengan melarutkan NPK ke dalam air PDAM, sehingga tingkat kekeruhan di awal relatif kecil. Hasil pengujian untuk parameter kekeruhan ditunjukkan pada Gambar 1.

Nilai kekeruhan digunakan untuk mengidikasikan keberadaan mikroorganisme (mikroalga dan EM4) di dalam sampel. Kadar kekeruhan hari ke-3 Gambar 1 menunjukkan peningkatan, hal ini menandakan terjadi fase pertumbuhan mikroorganisme di dalam reaktor. Kadar kekeruhan di hari ke-4 secara umum mengalami penurunan, dan ini menandakan bahwa fase pertumbuhan mikroorganisme telah mengalami penurunan. Fase hidup mikroorganisme dapat dilihat pada Gambar 2 [5][11]. Hari ke-11 fase penurunan yang terjadi semakin signifikan, kondisi ini menandakan bahwa mikroorganisme berada di fase kematian. 


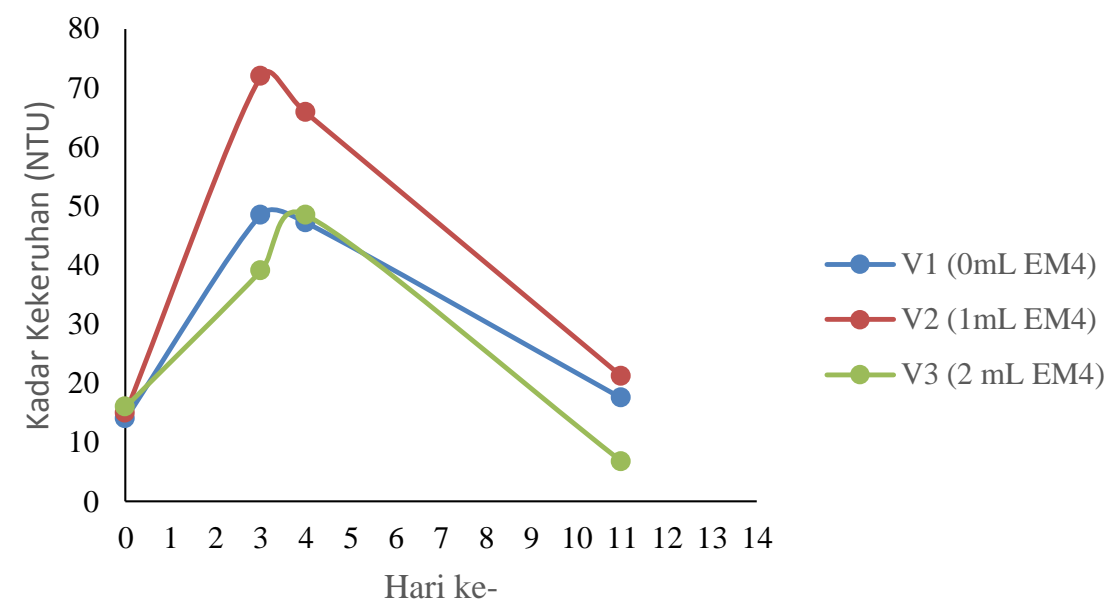

Gambar 1. Hasil pengujian sampel kekeruhan Sumber: Data penelitian, 2020

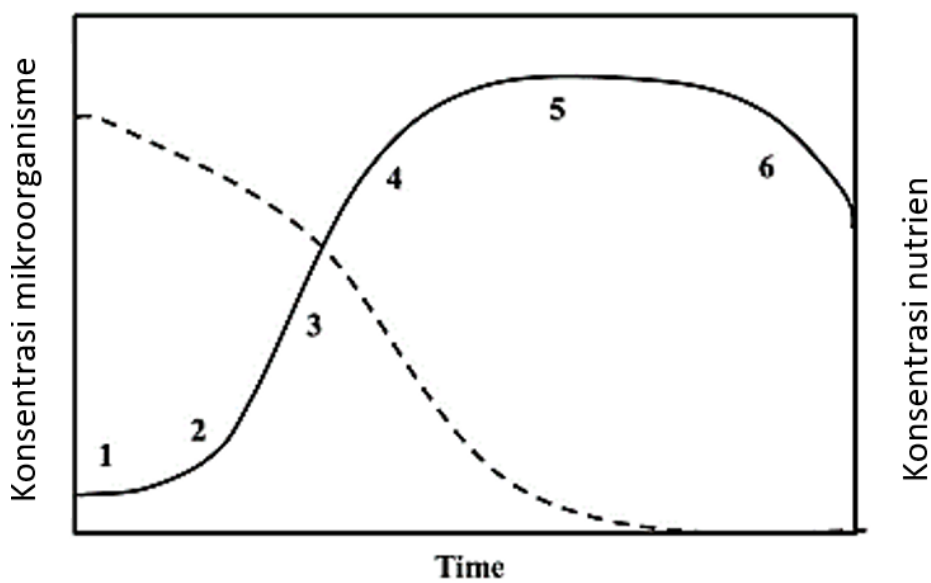

Gambar 2. Fase pertumbuhan mikrorganisme. Sumber: Data penelitian, 2020.

1. Fase lag

Fase lag merupakan fase pertumbuhan mikroorganisme yang masih terhambat karena mikroorganisme membutuhkan penyesuaian terhadap lingkungan baru di media kultur.

2. Fase eksponensial

Fase ini menunjukkan bahwa mikroorganisme mengalami pertumbuhan secara eksponensial. Mikroorganisme telah mensintesis enzim yang dapat menggunakan substrat pada medium untuk metabolisme. Ketersediaan enzim mengakibatkan jumlah mikroorganisme meningkat secara eksponensial.

3. Fase linear

Sel mikroorganisme mengalami perlambatan pada fase linear. Perlambatan terjadi karena nutrien mulai menjadi faktor pembatas.

4. Fase pengurangan pertumbuhan

Fase ini menunjukkan terjadinya penurunan pertumbuhan mikroorganisme. Penurunan terjadi karena faktor pembatas dalam pertumbuhan mikroorganisme semakin terlihat.

5. Fase stasioner

Pertumbuhan mikroorganisme berada di angka nol pada fase stasioner. Tidak terjadi pertumbuhan pada mikroorganisme karena jumlah nutrien pada media kultur telah habis.

6. Fase kematian

Fase ini menunjukkan telah terjadinya pengakumulasian pati dan lemak. Jumlah sel mikroorganisme mengalami penurunan secara cepat akibat kekurangan nutrien, gangguan $\mathrm{pH}$, kontaminasi, atau overheating. 
Mikroorganisme di dalam penelitian ini merupakan mikroorganisme gabungan dari mikroalga dan EM4 yang ditambahkan ke dalam dalam reaktor penenlitian. Penambahan EM4 sebesar $1 \mathrm{~mL}$ (variasi 2) dalam Gambar 1 menunjukkan kadar kekeruhan yang paling tinggi dibandingkan dengan variasi lain (tanpa penambahan EM4 dan penambahan EM4 $2 \mathrm{~mL}$ ). Hal ini berarti mengindikasikan bahwa pertumbuhan mikroorganisme pada variasi 2 lebih baik dibandingkan variasi lain.

Mikroalga pada dasarnya merupakan mikroorganisme yang mampu bertahan hidup hampir di semua perairan, asalkan terdapat nutrien dan karbon dioksida $\left(\mathrm{CO}_{2}\right)$ [12] yang cukup di dalam perairan tersebut. Karbondioksida $\left(\mathrm{CO}_{2}\right)$ ini bisa didapatkan dari EM4 (bakteri) [13]. Gambar 3 merupakan skema interaksi mikroalga dengan EM4 (bakteri).

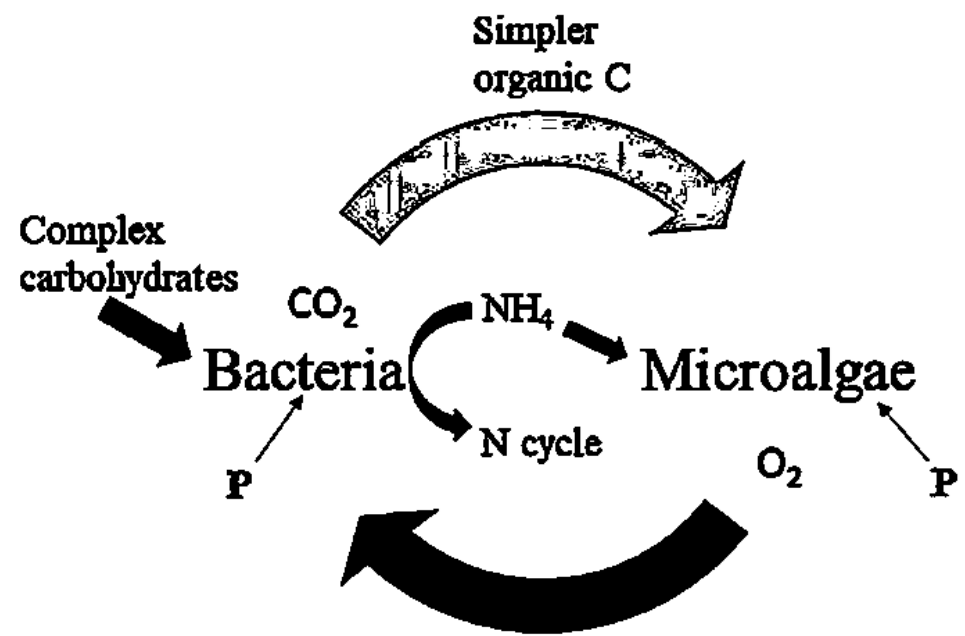

Gambar 3. Skema Interaksi Mikroalga-Bakteri Sumber: [14]

EM4 (bakteri) selain sebagai penyuplai $\mathrm{CO}_{2}$ dan $\mathrm{NH}_{4}$ untuk mikroalga, keberadaannya juga dapat dimanfaatkan untuk mereduksi polutan [15]. Karbohidrat komplek (polutan) akan dimanfaatkan oleh bakteri untuk pertumbuhan, sehingga dalam prosesnya bakteri akan merubah karbohidrat komplek tersebut menjadi $\mathrm{C}$ organik yang lebih simpel $\left(\mathrm{CO}_{2}\right)$ dan nutrien $\left(\mathrm{NH}_{4}\right)$ yang dibutuhkan oleh mikroalga. Berdasarkan penelitian yang telah dilakukan [4], [13], [15], pengolahan biologis dengan mikroalga yang ditambah mikroorganisme (bakteri) memiliki hasil yang lebih baik jika dibandingkan dengan menggunakan mikroalga saja.

Variasi 1 dan variasi 3 menunjukkan pertumbuhan mikroorganisme yang tidak terlalu signifikan seperti variasi 2. Variasi 1 tidak dilakukan penambahan EM4 ke dalam reaktor, sedangkan variasi 3 merupakan variasi dengan penambahan EM4 $2 \mathrm{~mL}$ ke dalam reaktor. Jika tidak dilakukan penambahan EM4 ke dalam reaktor, suplai $\mathrm{CO}_{2}$ tidak dapat tercukupi dengan baik. Suplai $\mathrm{CO}_{2}$ hanya bersumber dari udara lingkungan sekitar, sedangkan udara lingkungan sekitar lokasi penelitian tergolong cukup bersih karena tidak ada aktivitas sekitar yang menghasilkan polusi udara. Penambahan EM4 secara berlebih (2 $\mathrm{mL}$ ) juga berdampak tidak baik terhadap pertumbuhan mikroorganisme, karena dapat mengakibatkan cadangan sumber-sumber organik (NPK) yang ditambahkan ke dalam reaktor tidak mencukupi. Bakteri (EM4) tidak mendapatkan sumber karbohidrat komplek, sehingga tidak ada senyawa $\mathrm{CO}_{2}$ dan nutrien yang diperlukan oleh mikroalga. Kondisi ini didukung dengan penelitian yang dilakukan oleh [16], dalam penelitiannya disebutkan bahwa penurunan kadar Total Suspended Solid (TSS) tertinggi ditunjukkan pada perlakuan dengan penambahan EM-4 berlebih sebanyak $5 \mathrm{ml}$. Dalam penelitian tersebut, kandungan Total Suspended Solid (TSS) hari ke-3 tinggal 0,17 mg/l. Penurunan kadar TSS di perairan akan berimbas pula terhadap nilai kekeruhan. Kadar TSS di perairan sebanding dengan kadar kekeruhan, penelitian [17] menyatakan bahwa material tersuspensi dan terlarut di perairan tidak beracun, tetapi jika berlebihan, terutama TSS dapat meningkatkan nilai kekeruhan.

Gambar 4 merupakan diagram hasil pengujian parameter amonia pada penelitian dengan variasi penambahan EM4. 


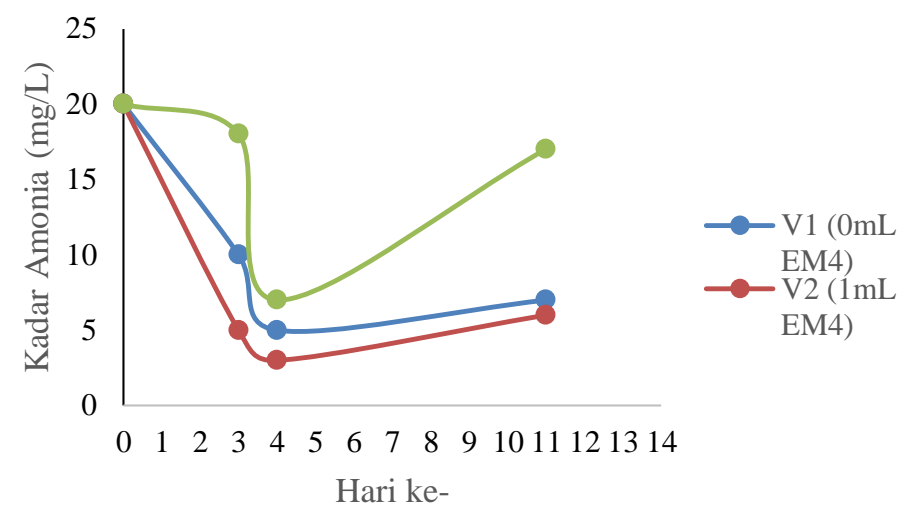

Gambar 4. Hasil pengujian sampel amonia (penambahan EM4) Sumber: Data penelitian, 2020

Secara umum kadar amonia (Gambar 4) menunjukkan penurunan dari hari ke-0 hingga hari ke-4. Penurunan kadar tersebut disebabkan karena amonia telah dimanfaatkan oleh mikroalga sebagai nutrisi dalam pertumbuhannya. Jika ditinjau dari penurunan kadar amonia di hari ke-3, penurunan terbesar ada pada variasi 2, kondisi ini sebanding dengan yang terjadi pada Gambar 1. Sementara Gambar 1 menunjukkan variasi 2 (penambahan $1 \mathrm{~mL}$ EM4) mengindikasikan adanya pertumbuhan mikroorganisme yang paling tinggi diantara variasi yang lain (tanpa penambahan EM4 dan penambahan EM4 $2 \mathrm{~mL}$ ). Kondisi ini menunjukkan bahwa keberadaan air limbah artifisial yang dilakukan dengan menambahkan bahan organik berupa NPK mampu memenuhi kebutuhan EM4, sehingga EM4 mampu mengubah bahan organik tersebut menjadi senyawasenyawa sederhana $\left(\mathrm{CO}_{2}\right.$ dan amonia) yang dibutuhkan oleh mikroalga. Simbiosis antara mikroalga dengan EM4 yang terjadi pada variasi 2 berlangsung dengan baik.

Penurunan kadar amonia yang cukup signifikan (Gambar 4) juga terjadi pada variasi 1 (penambahan 0 mL EM4), namun hal ini tidak sejalan dengan pertumbuhan mikroorganisme yang lebih tinggi seperti pada variasi 2 (penambahan $1 \mathrm{~mL}$ EM4) (Gambar 1). Variasi 1 tidak terdapat penambahan EM4, pertumbuhan mikroorganisme yang dimaksud hanya berasal dari mikroalga. Mikroalga mendapatkan cuplai $\mathrm{CO}_{2}$ hanya dari udara lingkungan sekitar. Adanya penurunan kadar amonia (Gambar 4) menandakan bahwa mikroalga telah menguptake amonia sebagai sumber nutrisi dalam proses fotosintesis.

Penurunan kadar amonia (Gambar 4) variasi 3 (penambahan $2 \mathrm{~mL}$ EM4) terlihat tidak begitu signifikan dibanding dengan variasi lain. Penambahan EM4 berlebih menyebabkan terjadinya uptake bahan organik oleh mikroorganisme menjadi tidak tercukupi dengan baik. Bahan organik yang ditambahkan ke dalam reaktor bersumber kandungan NPK cair (Tabel 2). Tidak tercukupinya bahan organik yang dibutuhkan oleh EM4 pada variasi 3 menyebabkan terjadinya kematian pada sebagian mikroorganisme. Hal ini ditandai dengan nilai kekeruhan (laju pertumbuhan mikroorganisme) variasi 3 tidak setinggi variasi 2, meskipun EM4 yang ditambahkan jumlahnya 2 kali lebih besar. Kondisi ini didukung oleh penelitian yang menyatakan bahwa pada hari-ke3, C-Organik [18] dan TSS [16] telah menurun. Penurunan C-Organik akan mengakibatkan berkurangnya sumber cadangan karbohidrat mikroorganisme, sehingga hal ini akan berdampak pada kematian sebagian mikroorganisme.

Sebagian mikroorganisme yang telah mengalami fase kematian, akan terurai kembali menjadi senyawasenyawa organik dan anorganik. Senyawa-senyawa organik tersebut akan dimanfaatkan kembali oleh EM 4 sebagai sumber karbohidrat, sedangkan senyawa-senyawa anorganik seperti amonia dan nutrien lain akan dimanfaatkan oleh mikroalga. Hari ke-11 pada Gambar 1 menunjukkan kadar kekeruhan menurun tajam. Fase kematian sangat jelas terlihat. Hal ini didukung dengan peningkatan kadar amonia di hari ke-11 (Gambar 4). Penelitian [19] juga menjelaskan bahwa telah terjadi peningkatan kadar amonia, nitrit, dan nitrat yang terlihat di hari ke 6 dan ke 9 yang disebabkan karena proses dekomposisi bahan organik telah mencapai batas maksimumnya.

\section{Kesimpulan}

Variasi penambahan $1 \mathrm{~mL}$ EM4 menunjukkan hasil yang lebih baik dari variasi $0 \mathrm{~mL}$ dan $2 \mathrm{~mL}$ EM4. Simbiosis mutualisme yang terjadi antara mikroalga dengan bakteri EM4 mampu menurunkan kadar amonia yang lebih tinggi dibanding variasi lain. Untuk penelitian lanjutan, sebaiknya pengujian sampel dilakukan dengan intensitas yang lebih sering, misalnya dilakukan setiap hari. Hal ini bertujuan supaya hasil pengamatan terhadap perubahan fase hidup mikroorganisme lebih terlihat jelas. 


\section{Ucapan Terima Kasih}

Ucapan terima kasih disampaikan kepada Kementerian Riset Teknologi dan Pendidikan Tinggi yang telah memberikan dukungan finansial kepada penulis dalam hibah penelitian dengan Skema Penelitian Dosen Pemula (Nomor kontrak : 005/LPPM.KT/UVERS/III/20).

\section{Referensi}

[1] S. Amini and R. Susilowati, "Produksi Biodiesel dari Mikroalga," Squalen, vol. 5, no. 1, pp. 23-32, 2010.

[2] M. B. Johnson and Z. Wen, "Development of an attached microalgal growth system for biofuel production," pp. 525-534, 2010.

[3] A. A. Fathi, M. M. Azooz, and M. A. Al-Fredan, "Phycoremediation and the potential of sustainable algal biofuel production using wastewater," Am. J. Appl. Sci., vol. 10, no. 2, pp. 189-194, 2013.

[4] Y. Zalfiatri, F. Restuhadi, and T. Maulana, "Pemanfaatan Simbiosis Mikroorganisme B-DECO3 dan Mikroalga Chlorella sp untuk Menurunkan Pencemaran Limbah Cair Pabrik Kelapa Sawit," Din. Lingkung. Indones., vol. 4, no. 1, p. 8, 2017.

[5] E. Lee, M. Jalalizadeh, and Q. Zhang, "Growth Kinetic Models for Microalgae Cultivation: A Review," ALGAL, vol. 12, pp. 497-512, 2015.

[6] A. S. Afifah, G. Prajati, Y. Adicita, and Y. W. Firmansyah, "Light And Nutrient Factors In The Growth Rate Of Microalgae: A Review," Int. J. Heal. Educ. Soc., vol. 3, no. 9, pp. 72-80, 2020.

[7] A. Bernhard, "The Nitrogen Cycle : Processes, Players, and Human Impact," Nat. Educ. Knowl., vol. 2 (2), no. 12, pp. 1-9, 2010.

[8] F. Restuhadi, Y. Zalfiatri, and T. Dahril, "Utilizing Symbiotic of Microalgae Chlorella sp . and EM4 to Reduce Levels of Pollutants of Sago Liquid Waste," in International Conference on Biology and Environmental Science, 2017, no. March, pp. 59-65.

[9] M. R. Apritama, I. W. K. Suryawan, A. S. Afifah, and I. Y. Septiariva, "Phytoremediation of Effluent Textile WWTP for NH3-N and Cu Reduction Using Pistia Stratiotes," Plant Arch., vol. 20, pp. 2384-2388, 2020.

[10] J. Tomperi, A. Isokangas, T. Tuuttila, and M. Paavola, "Functionality of turbidity measurement under changing water quality and environmental conditions," Environ. Technol., vol. 0, no. 0, pp. 19, 2020.

[11] E. Nazemi, "Biofunctionnalisées Photonic Monitoring of Biological Activities of Bacteria Immobilized on Biofunctionalized," 2017, no. January.

[12] A. W. D. Larkum, I. L. Ross, O. Kruse, and B. Hankamer, "Selection, breeding and engineering of microalgae for bioenergy and biofuel production," Trends Biotechnol., vol. 30, no. 4, pp. 198-205, 2012.

[13] F. B. Syarif, R. Faja, and Y. Zalfiatri, "Utilization of Symbiosis Microalgae Chlorella Sp and Agrobost to Reduce Sago Liquid Waste Pollutants," SAGU, vol. 18, no. 1, pp. 9-16, 2019.

[14] A. F. M. Udaiyappan et al., "Microalgae-bacteria interaction in palm oil mill e ffl uent treatment," $J$. Water Process Eng., vol. 35, no. February, pp. 1-12, 2020.

[15] F. Lananan et al., "Symbiotic Bioremediation of Aquaculture Wastewater in Reducing Ammonia and Phosphorus Utilizing Effective Microorganism (EM-1) and Microalgae (Chlorella sp.)," Int. Biodeterior. Biodegrad., vol. 95, no. PA, pp. 127-134, 2014.

[16] S. Haryaningsih, "Kefektifan EM-4 (Effective Microorganism-4) Dalam Menurunkan Total Suspended Solid (TSS) Pada Limbah Cair Industri Tahu Eko Suparjo Wirogunan Kartasura," Surakarta, 2015.

[17] T. B. Sanjoto, A. H. Elwafa, H. Tjahjono, and W. A. B. N. Sidiq, "Study of Total Suspended Solid Concentration Based on Doxaran Algorithm Using Landsat 8 Image In Coastal Water Between Bodri River Estuary Up to East Flood Canal Semarang City Study of Total Suspended Solid Concentration Based on Doxaran Algorithm Using L," in IOP Conference Series: Earth and Environmental Science, 2020, pp. 1-7.

[18] P. W. Ratrinia, Uju, and P. Suptijah, "Efektivitas Penambahan Bioaktivator Laut dan Limbah Cair Surimi pada Karakteristik Pupuk Organik Cair dari Sargassum sp.," JPHPI, vol. 19, pp. 309-320, 2016.

[19] N. T. M. Pratiwi, S. Hariyadi, I. P. Ayu, T. Apriadi, A. Iswantari, and D. Y. Wulandari, "Pengelolaan Kandungan Bahan Organik pada Limbah Cair Laboratorium Proling - MSP - IPB dengan Berbagai Kombinasi Agen Bioremediasi," J. Biol. Indones., vol. 15, no. 1, pp. 89-95, 2019. 